\title{
Allelopathic interactions between the bacillariophyte Skeletonema costatum and the raphidophyte Heterosigma akashiwo
}

\author{
Yasuhiro Yamasaki ${ }^{1, *}$, Sou Nagasoe ${ }^{1,2}$, Tadashi Matsubara ${ }^{1}$, Tomoyuki Shikata ${ }^{1}$, \\ Yohei Shimasaki ${ }^{1}$, Yuji Oshima ${ }^{1}$, Tsuneo Honjo ${ }^{1}$ \\ ${ }^{1}$ Laboratory of Marine Environmental Science, Division of Marine Biological Chemistry, Department of Bioscience and \\ Biotechnology, Faculty of Agriculture, Kyushu University, 6-10-1 Hakozaki, Higashi-ku, Fukuoka 812-8581, Japan \\ ${ }^{2}$ Present address: Harmful Algal Bloom Division, National Research Institute of Fisheries and Environment of Inlannd Sea, \\ 2-17-5 Maruishi, Hatsukaichi, Hiroshima 739-0452, Japan
}

\begin{abstract}
We investigated growth interactions between Skeletonema costatum (Greville) Cleve and Heterosigma akashiwo (Hada) Hada ex Hara et Chihara using bi-algal cultures under axenic conditions. When inoculated at high cell densities, growth of both species was coincidentally suppressed. In other combinations of inoculation density, the species first reaching stationary phase substantially reduced maximum cell densities of the other species. When cultured together under conditions without cell contact, growth of $S$. costatum and $H$. akashiwo were both suppressed. Furthermore, despite re-enrichment with nutrients, filtrates from dense cultures of $S$. costatum and $H$. akashiwo reciprocally reduced their maximum cell densities. In additional experiments, growth of Chaetoceros muelleri was also suppressed with filtrates from the above cultures, but growth of Prorocentrum minimum was not. Therefore, growth interactions between these species strongly suggest the involvement of allelopathic substances secreted by both species. Finally, growth and interaction of $S$. costatum and H. akashiwo in bi-algal cultures were simulated using a mathematical model. This model indicated that $S$. costatum and $H$. akashiwo steadily approach a stable equilibrium point of about $3.4 \times 10^{5}$ cells ml ${ }^{-1}$ and $4.8 \times 10^{5}$ cells $\mathrm{ml}^{-1}$, respectively, when the 2 species coexist.
\end{abstract}

KEY WORDS: Allelopathy - Bacillariophyceae - Skeletonema costatum • Raphidophyceae · Heterosigma akashiwo $\cdot \mathrm{Bi}$-algal culture $\cdot$ Growth inhibition

\section{INTRODUCTION}

Molisch (1937) introduced the term allelopathy to refer to biochemical interactions between all types of plants, including microorganisms. Rice (1974) defined allelopathy as any direct or indirect harmful effect by one plant, including microorganisms, on another through production of chemical compounds that escape into the environment. Later, Rice (1984) recanted his earlier definition because apparently most allelopathic compounds have both inhibitory and stimulatory effects on growth. Despite recent studies and reviews of the allelopathic interactions among marine and freshwater phytoplankton (Cembella 2003, Legrand et al. 2003), no satisfactory explanations have been provided to explain why certain phytoplankton species are able to completely dominate a phytoplank- ton community. Thus, we need to improve our understanding of the inhibitory and stimulatory interactions among many phytoplankton species in order to elucidate the role of allelopathy in algal succession and the outbreak mechanisms of algal blooms.

The diatom Skeletonema costatum (Greville) Cleve and the flagellate Olisthodiscus luteus Carter form alternating blooms in Narragansett Bay (Rhode Island, USA $_{i}$ Pratt 1966). In the fishing port of Hakozaki (Hakata Bay, Fukuoka, Japan), Honjo et al. (1978) found that several kinds of centric diatom disappeared temporarily during a Heterosigma sp. red tide. Note that Heterosigma akashiwo (Hada) Hada ex Hara et Chihara has been called $H$. inlandica Hada in Japan and has been confused with $O$. luteus in many countries (Honjo 1993). Hara \& Chihara (1987) reported that $H$. inlandica was synonymous with $H$. akashiwo, and 
Honjo (1994) and Smayda (1998) indicated that most pelagic blooms attributed to $O$. luteus were almost certainly those of $H$. akashiwo. Therefore, we will treat $O$. luteus described by Pratt (1966) and Honjo \& Tabata (1985) as H. akashiwo.

In in situ and in vitro experiments, high concentrations of Olisthodiscus luteus inhibit the growth of Skeletonema costatum, while lower concentrations stimulate the growth of $S$. costatum (Pratt 1966). Similarly, Honjo et al. (1978) reported that Heterosigma akashiwo and $S$. costatum alternated in forming red tide blooms in the fishing port of Hakozaki. They found that filtrate from dense cultures of $H$. akashiwo, reenriched with nutrients, suppressed the growth of $S$. costatum. Furthermore, Honjo \& Tabata (1985) reported an apparent and reciprocal codominance between $O$. luteus and diatoms in a $70 \mathrm{~m}^{3}$ outdoor tank with flowing coastal water.

Unfortunately, none of the in vitro experiments mentioned above used axenic strains. In this study, we used axenic strains of Heterosigma akashiwo and Skeletonema costatum. First, we conducted bi-algal culture experiments with several combinations of initial cell densities of the 2 species. Second, we examined allelopathic interactions between $H$. akashiwo and S. costatum by way of both growth experiments using culture filtrates and of bi-algal culture experiments under noncontact conditions. Finally, we simulated the growth of H. akashiwo and S. costatum in bi-algal cultures using a mathematical model and growth parameters derived from this study to quantify the relationships.

\section{MATERIALS AND METHODS}

Algal species and culture conditions. Axenic strains of Skeletonema costatum (NIES-324) and Heterosigma akashiwo (NIES-10) were obtained from the National Institute for Environmental Studies (NIES, Japan). An axenic strain of Chaetoceros muelleri Lemmermann (CCMP 1316) was obtained from the Provasoli-Guillard National Center for Culture of Marine Phytoplankton (CCMP, USA). Prorocentrum minimum (Pavillard) Schiller cells were isolated from the fishing port of Hakozaki, Fukuoka, Japan, in 1996 and were repeatedly washed using capillary pipettes. The above strains were tested for bacterial contamination using the fluorochrome 4',6-diamidino-2-phenylindole (DAPI) staining method (Porter \& Feig 1980); all were verified as axenic.

Cultures were maintained in $200 \mathrm{ml}$ flasks containing $100 \mathrm{ml}$ of modified sea water medium (SWM-3) (Table 1) from the original recipe (Chen et al. 1969) with a salinity of 25 at $25^{\circ} \mathrm{C}$ under $228( \pm 5) \mu \mathrm{mol} \mathrm{m}{ }^{-2} \mathrm{~s}^{-1}$ of cool-white fluorescent illumination on a 12:12 h light:dark cycle. The modified SWM-3 medium was autoclaved $\left(121^{\circ} \mathrm{C}, 15 \mathrm{~min}\right)$ and contained a $\mathrm{pH}$ buffer to avoid $\mathrm{pH}$ effects. Irradiance in the incubator was measured with a Quantum Scalar Laboratory Irradiance Sensor (QSL-2100/2101; Biospherical Instruments).

Bi-algal culture experiments. Bi-algal culture experiments were conducted in $100 \mathrm{ml}$ flasks containing $50 \mathrm{ml}$ of medium. Skeletonema costatum cells in stationary phase (10 to $\left.12 \times 10^{5} \mathrm{cells} \mathrm{ml}^{-1}\right)$ were inoculated at a final cell density of $10^{2}$ or $10^{4}$ cells ml ${ }^{-1}$ in all combinations into cultures of Heterosigma akashiwo (stock cultures: 5 to $6 \times 10^{5}$ cells $\mathrm{ml}^{-1}$ ) with cell densities of $10^{2}$ and $10^{4}$ cells ml- ${ }^{-1}$. As controls, both $S$. costatum and $H$. akashiwo were cultured individually at cell densities of $10^{2}$ and $10^{4} \mathrm{cells} \mathrm{ml}^{-1}$ (Table 2). Three replicate flasks were used for each treatment. All flasks were gently mixed by hand twice a day and randomly rearranged to minimize the effects of light or temperature gradients in the incubator. S. costatum and H. akashiwo cells were counted microscopically in $1000 \mu \mathrm{l}$ subsamples collected at $2 \mathrm{~d}$ intervals. When cell densities exceeded 20000 cells ml ${ }^{-1}$, subsamples were diluted 10 to $50 \times$ with fresh modified SWM-3 medium before counting. During the experiments, $\mathrm{pH}$ of each subsample collected for counting was measured using a $\mathrm{pH}-$ meter (B-212; Horiba).

Table 1. Components of modified SWM-3 medium

\begin{tabular}{|c|c|}
\hline Component & Quantity \\
\hline \multicolumn{2}{|l|}{ Modified SWM-3 medium } \\
\hline Seawater & $1000 \mathrm{ml}$ \\
\hline $\mathrm{NaNO}_{3}$ & $170 \mathrm{mg}$ \\
\hline $\mathrm{NaH}_{2} \mathrm{PO}_{4} \cdot 2 \mathrm{H}_{2} \mathrm{O}$ & $15.6 \mathrm{mg}$ \\
\hline $\mathrm{Na}_{2} \mathrm{EDTA}$ & $11.16 \mathrm{mg}$ \\
\hline Fe-EDTA & $0.84 \mathrm{mg}$ \\
\hline $\mathrm{NaSiO}_{3} \cdot 9 \mathrm{H}_{2} \mathrm{O}$ & $56.8 \mathrm{mg}$ \\
\hline P1-metal mixture solution ${ }^{1}$ & $10 \mathrm{ml}$ \\
\hline P2-metal mixture solution ${ }^{2}$ & $5 \mathrm{ml}$ \\
\hline Vitamin mixture solution ${ }^{3}$ & $5 \mathrm{ml}$ \\
\hline Tris (hydroxymethyl) aminomethane & $400 \mathrm{mg}$ \\
\hline \multicolumn{2}{|l|}{${ }^{1} \mathrm{P} 1-$ metal mixture solution } \\
\hline Distilled water & $1000 \mathrm{ml}$ \\
\hline EDTA & $1 \mathrm{~g}$ \\
\hline $\mathrm{MnCl}_{2} \cdot 4 \mathrm{H}_{2} \mathrm{O}$ & $0.69 \mathrm{~g}$ \\
\hline $\mathrm{CoCl}_{2} \cdot 6 \mathrm{H}_{2} \mathrm{O}$ & $2.38 \mathrm{mg}$ \\
\hline $\mathrm{ZnCl}_{2}$ & $54.8 \mathrm{mg}$ \\
\hline $\mathrm{H}_{2} \mathrm{SeO}_{3}$ & $173 \mu \mathrm{g}$ \\
\hline \multicolumn{2}{|l|}{${ }^{2}$ P2-metal mixture solution } \\
\hline Distilled water & $1000 \mathrm{ml}$ \\
\hline $\mathrm{H}_{3} \mathrm{BO}_{3}$ & $6.18 \mathrm{~g}$ \\
\hline \multicolumn{2}{|l|}{${ }^{3}$ Vitamin mixture solution } \\
\hline Distilled water & $500 \mathrm{ml}$ \\
\hline Vitamin $\mathrm{B}_{12}$ & $100 \mu g$ \\
\hline Vitamin $\mathrm{B}_{1}$ & $1 \mathrm{~g}$ \\
\hline Biotin & $100 \mu g$ \\
\hline
\end{tabular}


Macronutrient analyses. At the beginning of bi-algal experiments, $1 \mathrm{ml}$ of each culture was passed through a $0.22 \mu \mathrm{m}$ syringe filter (SLGV 025 LS; Millipore) and frozen at $-80^{\circ} \mathrm{C}$ until analysis. At the end of the bialgal experiments, $20 \mathrm{ml}$ of each culture was gravityfiltered through a $5.0 \mu \mathrm{m}$ pore size membrane filter (SMWP04700; Millipore) on a $47 \mathrm{~mm}$ polysulfone holder (KP-47H; Advantec). Filtrates were then passed through $0.22 \mu \mathrm{m}$ syringe filters and frozen at $-80^{\circ} \mathrm{C}$ until analysis of macronutrients. Nitrogen $\left(\mathrm{NO}_{2}{ }^{-}+\right.$ $\mathrm{NO}_{3}{ }^{-}$) and phosphorus $\left(\mathrm{PO}_{4}{ }^{3-}\right)$ were measured using an autoanalyzer (TRACCS 800; Bran + Luebbe) after samples were diluted 2 to $80 \times$ with Milli-Q water.

Bi-algal culture experiments under non-contact conditions. For these experiments, we used 6-well plates with BD Falcon cell culture insert plates (BD353091; Becton-Dickinson) (Fig. 1). This insert plate has a membrane filter (pore size $3.0 \mu \mathrm{m}$ ) on the bottom. Skeletonema costatum cells in stationary phase (10 to $12 \times 10^{5}$ cells $\mathrm{ml}^{-1}$ ) were suspended into modified SWM-3 medium at densities of $10^{2}$ and $10^{4}$ cells $\mathrm{ml}^{-1}$, and $5 \mathrm{ml}$ was inoculated into the outer chambers of the well plates. Heterosigma akashiwo cells in stationary phase $\left(5\right.$ to $6 \times 10^{5}$ cells ml $^{-1}$ ) were then suspended at a density of $10^{2}$ cells ml ${ }^{-1}$ in modified SWM-3 medium, and $3 \mathrm{ml}$ of the cell suspension was inoculated into each inner chamber. Similarly, $H$. akashiwo cells in stationary phase ( 5 to $6 \times 10^{5}$ cells $\mathrm{ml}^{-1}$ ) were diluted to densities of $10^{2}$ and $10^{4}$ cells ml $\mathrm{m}^{-1}$ with modified SWM3 medium, and $5 \mathrm{ml}$ was added into the outer chambers of the well plates. Skeletonema costatum cells in stationary phase $\left(10\right.$ to $12 \times 10^{5}$ cells $\left.\mathrm{ml}^{-1}\right)$ were then diluted to a density of $10^{2}$ cells $\mathrm{ml}^{-1}$ with modified SWM-3 medium, and $3 \mathrm{ml}$ of the cell suspension was added to the inner chambers of the well plates. Three replicate wells were used for each treatment. On Day 8 of the incubation, the cells in each of the five $10 \mu \mathrm{l} \mathrm{sub-}$ samples from each well were counted microscopically. If necessary, subsamples were diluted 10 to 50 times with fresh modified SWM-3 medium before counting.

Table 2. Skeletonema costatum and Heterosigma akashiwo. Initial cell densities for bi-algal culture experiments

\begin{tabular}{|lccc|}
\hline $\begin{array}{l}\text { H. akashiwo } \\
\left(\text { cells ml }{ }^{-1}\right)\end{array}$ & \multicolumn{3}{c}{$\begin{array}{c}\text { S. costatum } \\
(\text { cells ml }\end{array}$} \\
\cline { 2 - 4 } & 0 & $\left.10^{2}\right)$ & $10^{4}$ \\
\hline 0 & - & See & See \\
$10^{2}$ & & Fig. 2A,B & Fig. 2C,D \\
& See & See & See \\
$10^{4}$ & Fig. 2A,C & Figs. 2A \& 6A & Figs. 2C \& 6C \\
& See & See & See \\
& Fig. 2B,D & Figs. 2B \& 6B & Figs. 2D \& 6D \\
\hline
\end{tabular}

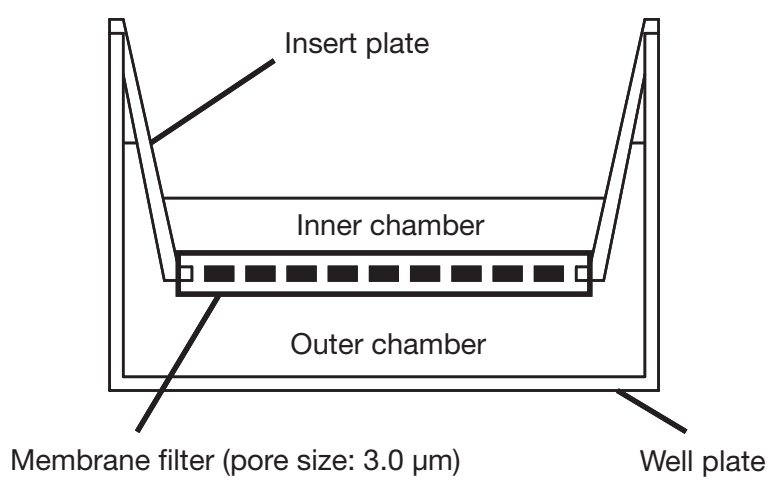

Fig. 1. Cross section of well plate with a BD Falcon cell culture insert

Effect of filtrates from Skeletonema costatum and Heterosigma akashiwo cultures on phytoplankton growth. For each species, $80 \mathrm{ml}$ samples from 5 replicate flasks were withdrawn by glass pipette after 1,3 , 5, 9 and $17 \mathrm{~d}$ (S. costatum) and 1, 5, 7, 11 and $17 \mathrm{~d}(H$. akashiwo), and passed through a $5.0 \mu \mathrm{m}$ pore size membrane filter on a $47 \mathrm{~mm}$ polysulfone holder under gravity filtration. Nutrients were added to the same concentrations as the modified SWM-3 medium in $80 \mathrm{ml}$ of each filtrate. As a control, an equal amount of Milli-Q water was added to $80 \mathrm{ml}$ of fresh modified SWM-3 medium. These filtrates were passed through $0.22 \mu \mathrm{m}$ syringe filters. Filtrates from both species were labeled in sequence of their growth as Phases I to V (see Fig. 4A,B). In addition, the pH of each filtrate was measured using a $\mathrm{pH}$-meter.

The effects of these filtrates from Skeletonema costatum and Heterosigma akashiwo cultures on growth of S. costatum, H. akashiwo, Chaetoceros muelleri, and Prorocentrum minimum were examined in 48-well plates. For each species, cells from cultures in stationary phase were diluted to a density of $10^{4}$ cells $\mathrm{ml}^{-1}$ with modified SWM-3 medium. Then $10 \mu \mathrm{l}$ of each cell suspension was inoculated into $990 \mu$ l of re-enriched filtrate of $S$. costatum and $H$. akashiwo (final cell density: $10^{2}$ cells $\mathrm{ml}^{-1}$ ), with 6 replicate wells for each treatment. After incubation $\left(S\right.$. costatum: $5 \mathrm{~d}_{i} H$.

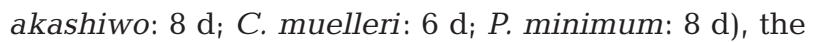
cells in each of the five $10 \mu \mathrm{l}$ subsamples from each well were counted microscopically. If necessary, subsamples were diluted 10 to 50 times with fresh modified SWM-3 medium before counting.

Effect of pH on phytoplankton growth rate. The growth rates of 4 phytoplankters were measured at different $\mathrm{pH}$ values between 7.8 and 9.1. The $\mathrm{pH}$ in modified SWM-3 medium was adjusted by the addition of $1 \mathrm{~N} \mathrm{HCl}$ or $\mathrm{NaOH}$. Growth was determined by daily measurement (Skeletonema costatum: 8 d; Heterosigma akashiwo: $7 \mathrm{~d}_{\text {; }}$ Chaetoceros muelleri: 5 to $6 \mathrm{~d}_{\text {; }}$ 
Prorocentrum minimum: 8 to 9 d) of in vivo fluorescence of cultures using a fluorometer (10-AU-005-CE; Turner Designs). Three replicate polystyrene tubes were used for each treatment.

Growth simulation in bi-algal cultures. To model the behavior of bi-algal cultures of Skeletonema costatum and Heterosigma akashiwo, we adopted the growth simulation of Uchida et al. (1999) using the following equations

$\mathrm{d} x \mathrm{~d} t^{-1}=r_{X} x\left[(1-x) K_{X}^{-1}\right]-A x y=r_{X} x\left[1-(x+a y) K_{X}^{-1}\right]$

$\mathrm{d} y \mathrm{~d} t^{-1}=r_{y} y\left[(1-y) K_{y}^{-1}\right]-B x y=r_{y} y\left[1-(b x+y) K_{y}^{-1}\right]$

Here, $x$ and $y$ are the cell densities of Skeletonema costatum and Heterosigma akashiwo, respectively. The parameters $r_{X}$ and $K_{X}$ are the growth rate and final cell density of $S$. costatum, respectively, and $r_{y}$ and $K_{Y}$ are the corresponding parameters for $H$. akashiwo when each species is in a mono-algal culture. $A$ is a measure of the degree of inhibition of $S$. costatum by $H$. akashiwo, and $B$ is that of $H$. akashiwo by $S$. costatum. If we set $A=a r_{x} K_{x}^{-1}$ and $B=b r_{y} K_{y}^{-1}$, then Eqs. (1) \& (2) become the same as the formulae for the growth of 2 populations competing with each other for

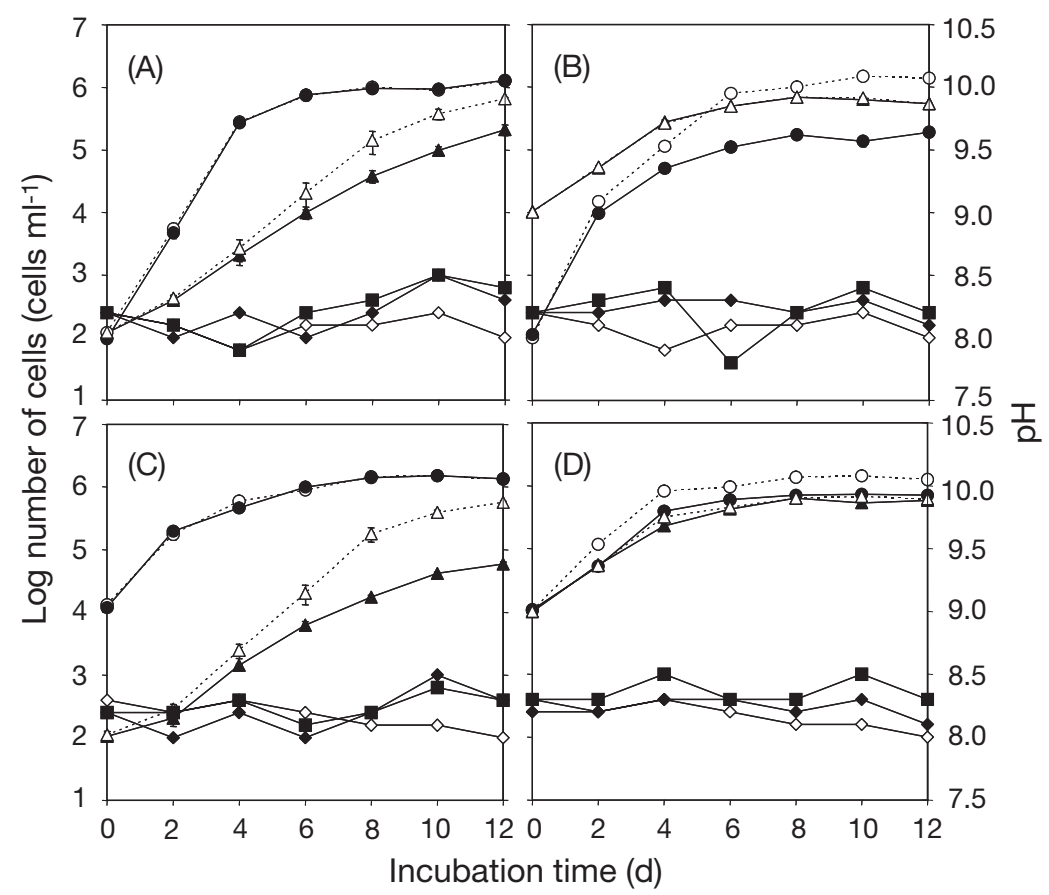

Fig. 2. Growth of Skeletonema costatum when cultured alone (O) or together with Heterosigma akashiwo $(\bullet)$, and of $H$. akashiwo when cultured alone $(\Delta)$ or together with $S$. costatum $(\boldsymbol{\Delta})$. Initial cell density of $S$. costatum was $10^{2}(\mathrm{~A}, \mathrm{~B})$ or $10^{4}$ cells ml ${ }^{-1}(\mathrm{C}, \mathrm{D})$; that of $H$. akashiwo was $10^{2}(\mathrm{~A}, \mathrm{C})$ or $10^{4} \mathrm{cells} \mathrm{ml}^{-1}(\mathrm{~B}, \mathrm{D})$. Data are mean \pm mean absolute deviation (MAD) (cells ml ${ }^{-1}$ ) of triplicate measurements; secondary $y$-axes indicate $\mathrm{pH}$ of bi-algal cultures (ם), and of $S$. costatum $(\diamond)$ and $H$. akashiwo $(\diamond)$ cultured alone. Errors are small and mostly obscured by the symbols limited resources (Iwasa 1998). Parameters $a$ and $b$ are non-dimensional and are a measure of the degree of inhibition by the other species compared with selfinterference. When each species is cultured in a monoalgal culture, we can set $a=b=0$.

The logistic parameters $\left(r_{x}, r_{y}, K_{x}, K_{Y}\right)$ were estimated by Eqs. (1) \& (2) using the mono-algal culture data from this study. Next, the parameters $a$ and $b$ were calculated directly from Eqs. (1) \& (2) using the bi-algal culture data. Precise estimates of $a$ and $b$ were carried out using the Marquardt method (Marquardt 1963), with the most appropriate values of $a$ and $b$ determined when the difference between the squared values of observed cell density and theoretical cell density became minimum.

\section{RESULTS}

\section{Bi-algal culture experiments}

When initial cell densities of both Skeletonema costatum and Heterosigma akashiwo were $10^{2}$ cells $\mathrm{ml}^{-1}$, the growth of $S$. costatum was virtually the same in both bi-algal and mono-algal cultures (Fig. 2A). In contrast, the growth of $H$. akashiwo was gradually suppressed from Day 6 onwards-when $S$. costatum reached stationary phase-after which the average maximum cell density of $H$. akashiwo was about $32 \%$ of that in mono-algal cultures (Fig. 2A).

When initial cell densities of Skeletonema costatum and Heterosigma akashiwo were $10^{2}$ cells $\mathrm{ml}^{-1}$ and $10^{4}$ cells $\mathrm{ml}^{-1}$, respectively, the growth of $H$. akashiwo was virtually the same in both bi-algal and mono-algal cultures. In contrast, the growth of $S$. costatum became remarkably suppressed in bialgal cultures beginning on Day 4 when $H$. akashiwo reached stationary phase, after which the average maximum cell density of $S$. costatum was about $13 \%$ of that in mono-algal cultures (Fig. 2B).

When initial cell densities of Skeletonema costatum and Heterosigma akashiwo were $10^{4}$ cells ml $\mathrm{m}^{-1}$ and $10^{2}$ cells $\mathrm{ml}^{-1}$, respectively, the growth of $S$. costatum in both bi-algal and monoalgal cultures was virtually the same. In contrast, the growth of $H$. akashiwo was significantly suppressed in bi-algal cultures beginning on Day 4 when 
Table 3. Skeletonema costatum and Heterosigma akashiwo. Initial and final macronutrient concentrations ( \pm MAD) for bi-algal culture experiments with mono-algal controls

\begin{tabular}{|c|c|c|c|c|c|c|}
\hline \multirow[t]{2}{*}{ Culture } & \multirow[t]{2}{*}{ Species } & \multirow{2}{*}{$\begin{array}{l}\text { Initial cell density } \\
\quad\left(\text { cells ml } \mathrm{m}^{-1}\right)\end{array}$} & \multicolumn{2}{|c|}{$-\mathrm{NO}_{2}^{-}+\mathrm{NO}_{3}^{-}(\mu \mathrm{M})-$} & \multicolumn{2}{|c|}{$-\mathrm{PO}_{4}^{3-}(\mu \mathrm{M})$} \\
\hline & & & Day 0 & Day 12 & Day 0 & Day 12 \\
\hline \multirow[t]{3}{*}{ Mono-algal } & S. costatum & $10^{2}$ & $1095 \pm 58.01$ & $250 \pm 24.10$ & $50 \pm 0.89$ & $0.627 \pm 0.12$ \\
\hline & & $10^{4}$ & $1166 \pm 5.03$ & $277 \pm 4.82$ & $51 \pm 0.80$ & $0.650 \pm 0.01$ \\
\hline & H. akashiwo & $\begin{array}{l}10^{2} \\
10^{4}\end{array}$ & $\begin{array}{l}1159 \pm 11.95 \\
1143 \pm 10.26\end{array}$ & $\begin{aligned} 180 & \pm 52.30 \\
0.369 & \pm 0.23\end{aligned}$ & $\begin{array}{l}52 \pm 0.30 \\
49 \pm 0.32\end{array}$ & $\begin{array}{l}0.500 \pm 0.14 \\
0.308 \pm 0.08\end{array}$ \\
\hline \multirow[t]{4}{*}{ Bi-algal } & S. costatum & $\begin{array}{l}10^{2} \\
10^{2}\end{array}$ & $1121 \pm 15.06$ & $106 \pm 45.90$ & $52 \pm 1.21$ & $0.415 \pm 0.09$ \\
\hline & $\begin{array}{l}\text { S. costatum } \\
\text { H. akashiwo }\end{array}$ & $\begin{array}{l}10^{2} \\
10^{4}\end{array}$ & $1153 \pm 8.48$ & $0.395 \pm 0.10$ & $53 \pm 1.05$ & $0.294 \pm 0.12$ \\
\hline & $\begin{array}{l}\text { S. costatum } \\
\text { H. akashiwo }\end{array}$ & $\begin{array}{l}10^{4} \\
10^{2}\end{array}$ & $1138 \pm 19.15$ & $93.8 \pm 8.97$ & $50 \pm 1.69$ & $0.923 \pm 0.18$ \\
\hline & $\begin{array}{l}\text { S. costatum } \\
\text { H. akashiwo }\end{array}$ & $\begin{array}{l}10^{4} \\
10^{4}\end{array}$ & $1136 \pm 34.56$ & $0.174 \pm 0.14$ & $49 \pm 2.31$ & $0.300 \pm 0.03$ \\
\hline
\end{tabular}

S. costatum cells reached stationary phase, after which the average maximum cell density of $H$. akashiwo was about $9 \%$ of that in mono-algal cultures (Fig. 2C).

When initial cell densities of Skeletonema costatum and Heterosigma akashiwo were both $10^{4}$ cells $\mathrm{ml}^{-1}$, the growth of $H$. akashiwo became weakly suppressed. The growth of $S$. costatum became slightly suppressed beginning on Day 2, after which the average maximum cell density of $S$. costatum was about $50 \%$ of that in mono-algal cultures (Fig. 2D).

Macronutrient analysis on samples from all cultures indicated that nitrogen $\left(\mathrm{NO}_{2}^{-}+\mathrm{NO}_{3}^{-}\right)$and phosphorus $\left(\mathrm{PO}_{4}{ }^{3-}\right)$ concentrations significantly decreased in cultures with initial Heterosigma akashiwo cell densities of $10^{4}$ cells $\mathrm{ml}^{-1}$ compared with those with initial cell densities of $10^{2}$ cells $\mathrm{ml}^{-1}$ (Table 3 ).
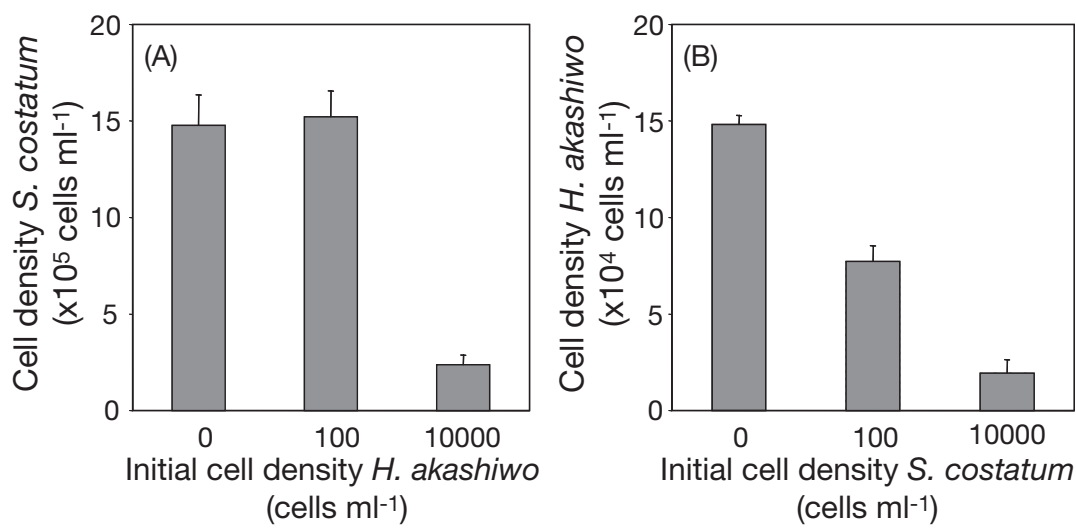

Fig. 3. Skeletonema costatum and Heterosigma akashiwo. Bi-algal cultures under non-contact conditions. (A) Effects of $H$. akashiwo (initial cell density: $10^{2}$ and $10^{4}$ cells $\mathrm{ml}^{-1}$ ) on growth of $S$. costatum (initial cell density: $10^{2}$ cells $\mathrm{ml}^{-1}$ ). (B) Effects of $S$. costatum (initial cell density: $10^{2}$ and $10^{4}$ cells ml ${ }^{-1}$ ) on growth of $H$. akashiwo (initial cell density: $10^{2}$ cells $\mathrm{ml}^{-1}$ ). Data are mean \pm MAD (cells $\mathrm{ml}^{-1}$ ) of triplicate measurements

\section{Bi-algal culture experiments under non-contact conditions}

Growth of Skeletonema costatum (initial cell density: $10^{2}$ cells $\mathrm{ml}^{-1}$ ) in bi-algal cultures with Heterosigma akashiwo (initial cell density: $10^{2}$ or $10^{4}$ cells $\mathrm{ml}^{-1}$ ) under the non-contact conditions provided by cell culture inserts was substantially inhibited $(16 \%$ of the control) by $H$. akashiwo when initial cell density was $10^{4}$ cells ml $\mathrm{ml}^{-1}$ (Fig. 3A). In contrast, growth of $H$. akashiwo was not inhibited by $S$. costatum under these conditions. Growth inhibition of $H$. akashiwo (initial cell density: $10^{2}$ cells $\mathrm{ml}^{-1}$ ) in bi-algal cultures with $S$. costatum (initial cell density: $10^{2}$ or $10^{4}$ cells $\mathrm{ml}^{-1}$ ) under the same non-contact conditions was dependent on the cell density of $S$. costatum (Fig. 3B). In contrast, growth of $S$. costatum was not inhibited by $H$. akashiwo under these conditions.

\section{Effects of culture filtrates on phytoplankton growth}

We observed the effects of filtrates from Skeletonema costatum cultures (Phase I to V) on the growth of Heterosigma akashiwo, Chaetoceros muelleri and Prorocentrum minimum cultures (initial cell densities: $10^{2}$ cells $\mathrm{ml}^{-1}$; Fig. 4A). Enriched filtrates from $S$. costatum cultures in Phases III and IV substantially decreased the growth of H. akashiwo (Phases III: $48 \%$ of control; Phase IV: $18 \%$ of control) and $C$. muelleri (Phase III: $43 \%$ of control; Phase IV: $28 \%$ of control), whereas 
filtrates from $S$. costatum cultures in Phase V only slightly decreased the growth of $H$. akashiwo and $C$. muelleri (Fig. 4Ai,Aii). Enriched filtrates from S. costatum cultures had little effect on the growth of $P$. minimum (Fig. 4Aiii).

Similarly, we observed the effects of enriched filtrates from Heterosigma akashiwo cultures (Phase I to V) on the growth of Skeletonema costatum, Chaetoceros muelleri and Prorocentrum minimum (initial cell density: $10^{2}$ cells $\mathrm{ml}^{-1}$; Fig. 4B). The filtrates from $H$. akashiwo cultures in Phases III and V substantially decreased the growth of $S$. costatum and C. muelleri (Fig. 4Bi, Bii). Enriched filtrates from $H$. akashiwo cultures had little effect on the growth of P. minimum (Fig. 4Biii).
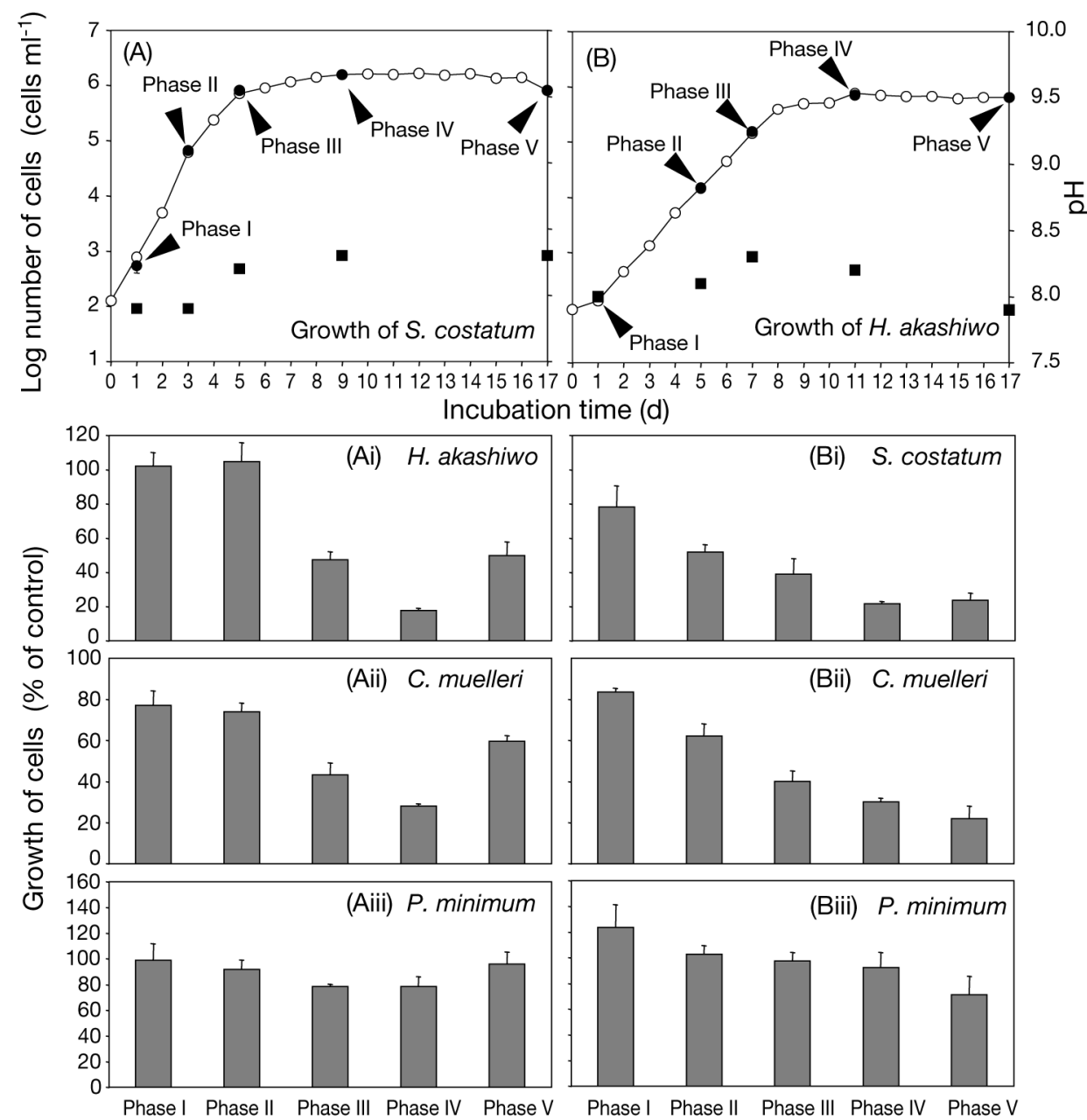

Fig. 4. Effects of culture filtrate on phytoplankton growth. (A) Growth curve of Skeletonema costatum showing collection times of filtrate and effects of filtrate on (Ai) Heterosigma akashiwo, (Aii) Chaetoceros muelleri and (Aiii) Prorocentrum minimum. (B) Growth curve of $H$. akashiwo showing collection times of filtrate and effects of filtrate on (Bi) S. costatum, (Bii) C. muelleri and (Biii) P. minimum. Data are mean $\pm \mathrm{MAD}\left(\right.$ cells ml $\left.{ }^{-1}\right)$ of triplicate measurements; secondary $y$-axes $(\mathrm{A}, \mathrm{B})$ indicate $\mathrm{pH}(\mathbf{\square})$

Table 4. Skeletonema costatum and Heterosigma akashiwo. Estimated parameters for bi-algal model simulation. a and $b$ are dimensionless. (For details and definition of $A, B$, see 'Growth simulation in bi-algal cultures' in 'Materials and methods')

\begin{tabular}{|c|c|c|c|c|c|}
\hline \multirow[t]{3}{*}{ Species } & \multirow{3}{*}{$\begin{array}{c}\text { Carrying capacity } \\
(K) \\
\left(\text { cells ml } l^{-1}\right)\end{array}$} & \multirow{2}{*}{\multicolumn{2}{|c|}{$\underset{(r)}{\text { Growth rate }}$}} & \multicolumn{2}{|c|}{ Interaction rate } \\
\hline & & & & $(a$ or $b)$ & $(A$ or $B)$ \\
\hline & & (divisions $\mathrm{h}^{-1}$ ) & (divisions $\mathrm{d}^{-1}$ ) & & $\left(\mathrm{ml} \mathrm{cell}{ }^{-1} \mathrm{~s}^{-1}\right)$ \\
\hline S. costatum & 1144459 & 0.068 & 1.63 & 1.668 & $2.8 \times 10^{-11}$ \\
\hline H. akashiwo & 583528 & 0.042 & 1 & 0.302 & $6.0 \times 10^{-12}$ \\
\hline
\end{tabular}




\section{Effect of culture $\mathrm{pH}$ on phytoplankton growth rate}

The effect of $\mathrm{pH}$ on the growth of 4 phytoplankton species was tested over the $\mathrm{pH}$ range of 7.8 to 9.1 (Fig. 5). The growth rate of Skeletonema costatum declined by $20 \%$ at a $\mathrm{pH}$ of 8.78 , and a similar reduction was observed in the growth rate of Heterosigma akashiwo and Chaetoceros muelleri at a $\mathrm{pH}$ of 8.94 . There was no observed effect of $\mathrm{pH}$ on the growth rate of Prorocentrum minimum over the range tested.

\section{Growth simulation in bi-algal cultures}

The values of all parameters of the growth simulation are shown in Table 4 . Note that the growth patterns of bi-algal cultures of Skeletonema costatum and Heterosigma akashiwo predicted using these values are similar to those observed in the culture experiments (Fig. 6).

\section{DISCUSSION}

\section{Allelopathy between Skeletonema costatum and Heterosigma akashiwo}

Previous bi-algal culture experiments with Skeletonema costatum and Heterosigma akashiwo were not conducted under axenic conditions. For example, Imai et al. (1995), Nagasaki et al. (1994a,b) and Tarutani et al. (2000) reported that bacterial attack and viral infection induce bloom termination. To reveal the allelopathic interactions between phytoplankton species, we conducted bi-algal culture experiments using axenic cultures of $S$. costatum and $H$. akashiwo.

The species first reaching stationary phase substantially suppressed the maximum cell densities attained by the second species (Fig. 2A-C). These results may explain observations that Heterosigma akashiwo and Skeletonema costatum alternately dominate in the field and in laboratory experiments under non-axenic conditions (Pratt 1966, Honjo et al. 1978). Pratt (1966) and Honjo et al. (1978) observed that after the decline of $S$. costatum blooms, $H$. akashiwo multiplied and formed blooms. The fact that the growth rate of $S$. costatum is higher than that of $H$. akashiwo (Fig. 2A) may explain why blooms of $S$. costatum usually precede those of $H$. akashiwo in the field. Furthermore, our laboratory results agree with field observations that during the bloom of one species, the other species disappears (Fig. 2B,C). Interestingly, when the initial cell densities of $S$. costatum and $H$. akashiwo in bialgal cultures were both $10^{4}$ cells ml-1 ${ }^{-1}$, growth of both species was slightly suppressed, but the effects of

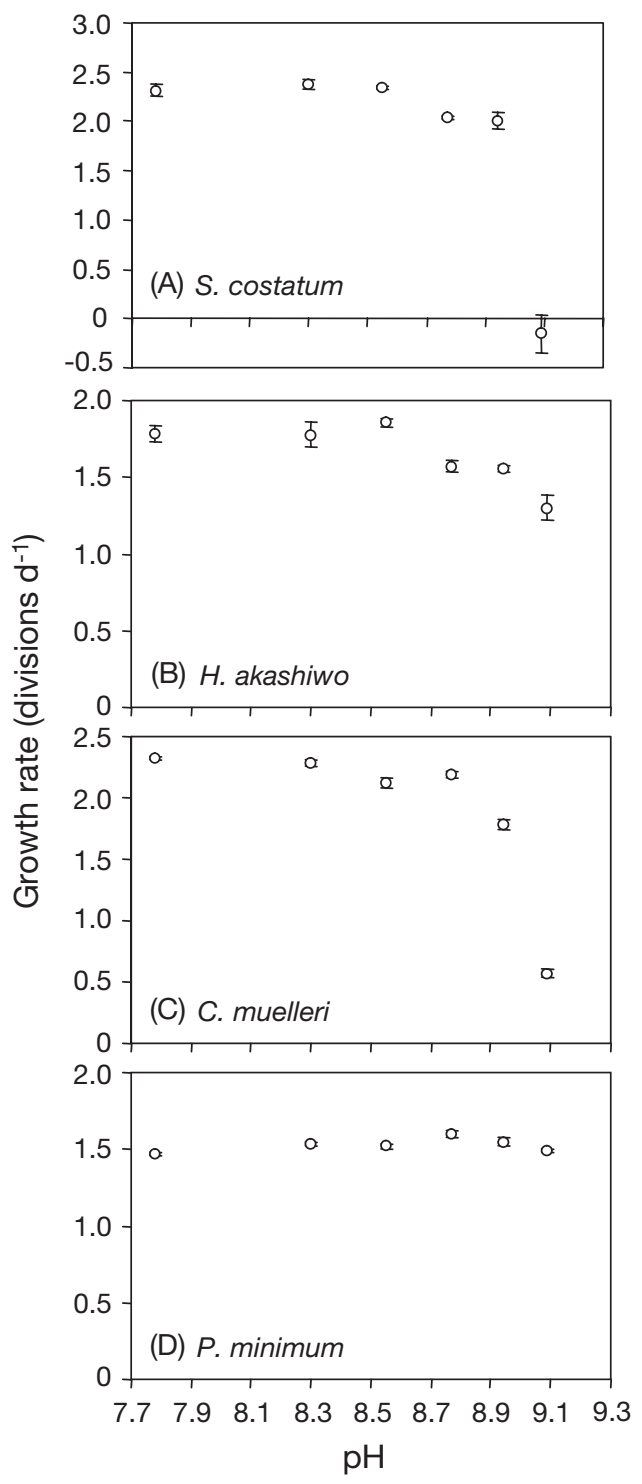

Fig. 5. Growth rates of cultures of (A) Skeletonema costatum, (B) Heterosigma akashiwo, (C) Chaetoceros muelleri and (D) Prorocentrum minimum with culture $\mathrm{pH}$ values ranging from 7.8 to 9.1. Data are mean \pm MAD (cells ml ${ }^{-1}$ ) of triplicate measurements

growth inhibition were weaker than in other experimental groups (Fig. 2D). Therefore, allelopathic substances of $S$. costatum and $H$. akashiwo may react antagonistically at certain concentrations.

Our experiments with bi-algal cultures under noncontact conditions (Fig. 3) and with re-enriched culture filtrates (Fig. 4) indicated that substances secreted or released by Skeletonema costatum and Heterosigma akashiwo inhibited the growth of the other species, and that these inhibitions were not caused by light, nutrients or cell contact (Uchida et al. 1995, 1999). These results successfully demonstrate that allelopathy is involved in the growth interactions between 


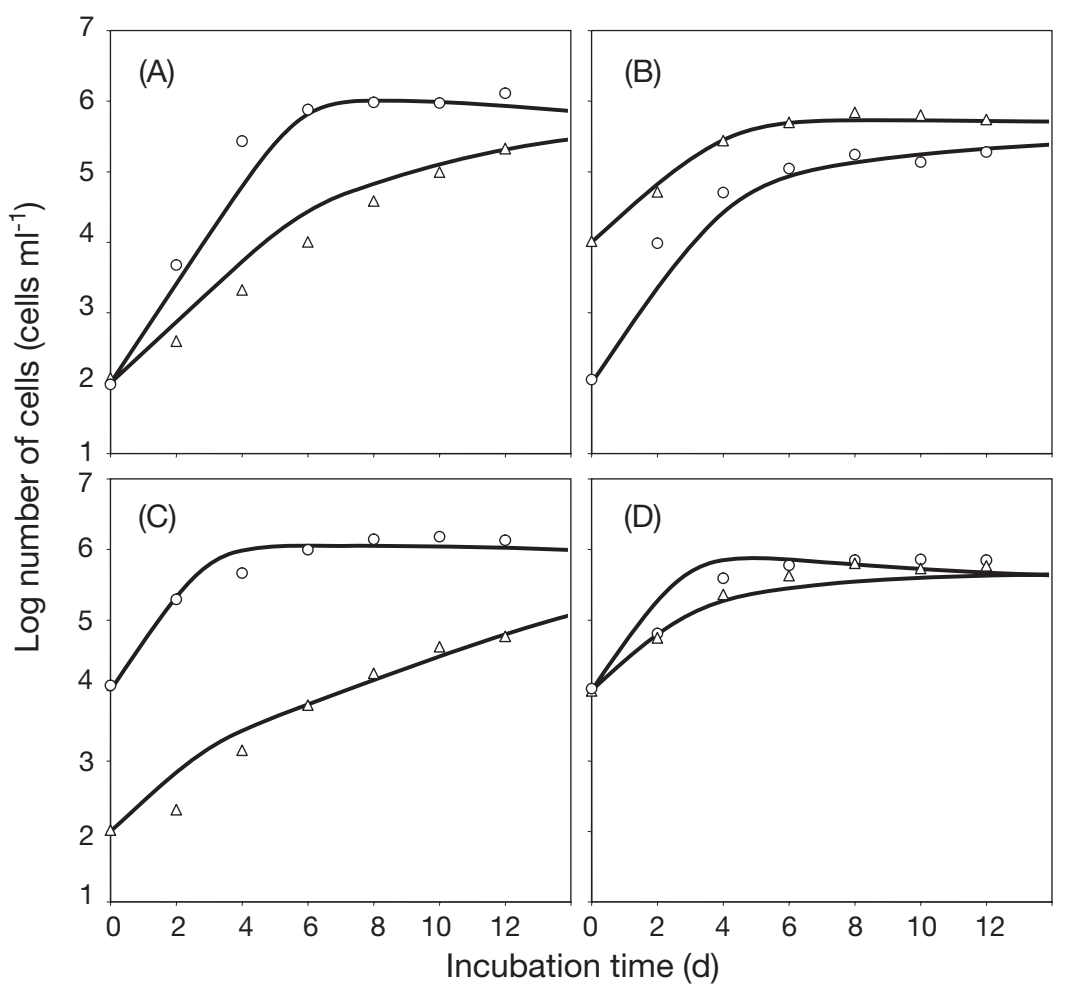

Fig. 6. Growth simulation of Skeletonema costatum and Heterosigma akashiwo in bi-algal cultures for various combinations of initial cell densities. (A) $S$. costatum $10^{2}$ cells ml ${ }^{-1}, H$. akashiwo $10^{2}$ cells ml ${ }^{-1}$; (B) S. costatum $10^{2}$ cells ml ${ }^{-1}, H$. akashiwo $10^{4}$ cells ml ${ }^{-1}$; (C) $S$. costatum $10^{4}$ cells ml ${ }^{-1}, H$. akashiwo $10^{2}$ cells ml ${ }^{-1}$; (D) S. costatum $10^{4}$ cells ml ${ }^{-1}, H$. akashiwo $10^{4}$ cells ml ${ }^{-1}$. Lines show simulated growth curves and symbols show actual data from bi-algal cultures: $\mathrm{O}, \mathrm{S}$. costatum; $\Delta, H$. akashiwo

S. costatum and $H$. akashiwo. Additionally, our results agree with Pratt's (1966) results that filtrate from Olisthodiscus luteus at a high cell density inhibits the growth of $S$. costatum; however, the inhibitory effects of $S$. costatum on $H$. akashiwo observed in this work were not evident in his results. This difference may result from the effects of bacteria or the use of different strains.

Enriched filtrates from Skeletonema costatum and Heterosigma akashiwo cultures decreased the growth of Chaetoceros muelleri, but had little effect on the growth of Prorocentrum minimum, suggesting that effects of allelopathic substances from $S$. costatum and H. akashiwo may be species-specific (Fig. 4). Furthermore, the inhibitory effects of enriched filtrates from Phase V S. costatum cultures were weaker than those of filtrates from Phases III and IV (Fig. 4A), suggesting that the allelopathic substances are relatively unstable. In contrast, the allelopathic substances of $H$. akashiwo are relatively stable (Fig. 4B). Therefore, allelopathic substances of $S$. costatum and $H$. akashiwo are probably different in chemical nature.
Heil et al. (2005) suggested that Prorocentrum minimum blooms were related to the intensity of Skeletonema costatum and Heterosigma akashiwo blooms. In this study, we found that enriched filtrates from $S$. costatum and $H$. akashiwo cultures had little effect on the growth of $P$. minimum (Figs. 4Aiii, Biii); however, we did not investigate the growth interactions between these species in detail. Future field studies should examine the growth interactions between species that occur with, precede or succeed a target species, for example P. minimum.

According to Pratt (1966), the inhibition of Skeletonema costatum growth in Olisthodiscus luteus filtrates is primarily due to an ectocrine, a tanninlike substance released by $O$. luteus. However, Honjo (1993) suggested that a polysaccharide-protein complex exfoliated from the cell surface or excreted by Heterosigma akashiwo acts as an allelopathic substance causing dramatic changes in cell numbers of other phytoplankton species during H. akashiwo blooms. Kondo et al. (1990) showed that organic substances excreted by $S$. costatum in culture increased Prorocentrum minimum cell yield. In recent years, a negative influence of diatom-derived $\alpha-, \beta-, \gamma-$, and $\delta$-unsaturated aldehydes (PUAs) on the reproductive success of copepods and other invertebrates has been suggested (Ianora et al. 2004, Pohnert 2005, Wichard et al. 2005), and it is necessary to examine the growth effects of S. costatum-derived PUAs on phytoplankters. Unfortunately, these allelopathic substances inhibiting the growth of $S$. costatum and $H$. akashiwo have not yet been identified.

\section{Effects of pH on growth of 4 phytoplankton species}

Recently, some studies indicated that elevated $\mathrm{pH}$ in culture media inhibited the growth of phytoplankters in mixed cultures (Goldman et al. 1981, 1982, Schmidt \& Hansen 2001, Lundholm et al. 2005). Therefore, when studying interactions between algae in dense cultures, an elevated $\mathrm{pH}$ in the growth media is an important consideration. During our bi-algal culture experiments, the $\mathrm{pH}$ ranged from 7.8 to 8.5 (Fig. 2). Moreover, the $\mathrm{pH}$ of filtrates from different phases (I to 
V) of 2 species ranged from 7.9 to 8.3 (Fig. 4). The growth rates of the 4 phytoplankton species used in this study were not affected by $\mathrm{pH}$ values in these ranges (Fig. 5).

Hansen (2002) measured $\mathrm{pH}$ in the surface waters of the eutrophic Mariager Fjord, Denmark, over $10 \mathrm{yr}$ (1990 to 1999) and reported profound seasonal variation. He also reported that some species were very sensitive to high $\mathrm{pH}$, while others could grow at their maximum growth rate even at high $\mathrm{pH}$. In comparison, we demonstrated that allelopathy between Skeletonema costatum and Heterosigma akashiwo exists. Thus, we believe that allelopathy, possibly along with seasonal variations in environmental factors such as $\mathrm{pH}$, is involved in phytoplankton succession and interactions between $S$. costatum and $H$. akashiwo in the field.

\section{Equilibrium point of Skeletonema costatum and Heterosigma akashiwo}

The values of the parameters in Table 4 were used to calculate isoclines (where $\mathrm{d} x \mathrm{~d} t^{-1}=0$ or $\mathrm{d} y \mathrm{~d} t^{-1}=0$ ) and trajectories of populations of the 2 species under various initial cell densities (Fig. 7). The equilibrium point (where $\mathrm{d} x \mathrm{~d} t^{-1}=\mathrm{d} y \mathrm{~d} t^{-1}=0$ ) is reached at $x$ (Skeletonema costatum $)=3.4 \times 10^{5}$ cells $\mathrm{ml}^{-1}$ and $y$ (Heterosigma akashiwo $)=4.8 \times 10^{5}$ cells $\mathrm{ml}^{-1}$. This model indicates that $S$. costatum and $H$. akashiwo steadily approach a stable equilibrium point at which the 2 spe-

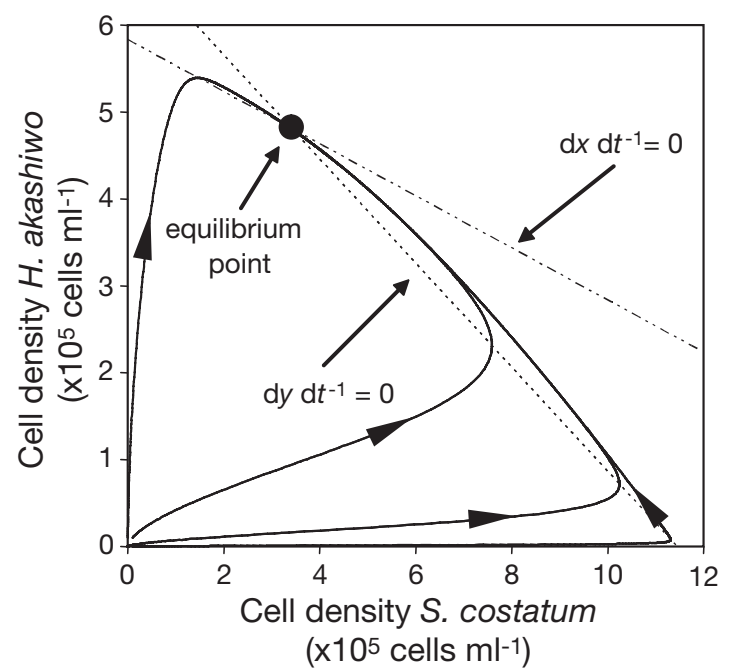

Fig. 7. Skeletonema costatum and Heterosigma akashiwo. Bialgal culture simulation isoclines (where $\mathrm{dxd} t^{-1}=0$ or $\mathrm{dyd} t^{-1}=$ 0 ) and trajectories of $S$. costatum and $H$. akashiwo with various initial cell densities. Regardless of initial cell densities, $S$. costatum and $H$. akashiwo steadily approach a stable equilibrium point at which final cell densities are approx. $3.4 \times$ $10^{5}$ cells ml ${ }^{-1}$ and $4.8 \times 10^{5}$ cells $\mathrm{ml}^{-1}$, respectively cies can coexist because $K_{x}>a K_{Y}$ and $b K_{x}<K_{y}$ (Iwasa 1998).

Uchida et al. (1999) reported that, based on a mathematical model, the inhibition of Gymnodinium (=Karenia) mikimotoi Miyake et Kominami ex Oda by Heterocapsa circularisquama Horiguchi is $3 \times$ greater than the inhibition of $H$. circularisquama by $G$. mikimotoi. Nagasoe et al. (2006) found that the growth inhibition of Gyrodinium instriatum Freudenthal \& Lee by Skeletonema costatum may require cell contact, but that $G$. instriatum did not affect $S$. costatum. Their equilibrium point was $5 \times 10^{3}$ cells $\mathrm{ml}^{-1}$ (G. instriatum) and $12 \times$ $10^{5}$ cells $\mathrm{ml}^{-1}$ (S. costatum). These results differ from ours in terms of equilibrium point values and in the effects of allelopathy vs. cell contact.

\section{Significance of allelopathy}

Allelopathy is of special interest from an evolutionary perspective. Secondary metabolites apparently function as defense (against herbivores, microbes, viruses or competing plants) and signal compounds (to attract pollinating or seed-dispersing animals), and represent adaptive characters that have been subjected to natural selection during evolution (Michael 2003). Allelopathic substances secreted by Skeletonema costatum and Heterosigma akashiwo may favor the 2 species in competition with other phytoplankton species as well as higher plants. In this study, when one species reached stationary phase in bi-algal cultures, the maximum cell densities of the other species decreased substantially (Fig. 2). This result suggests that allelopathic substances of these 2 species affect each other reciprocally when red tide blooms are formed by only $S$. costatum or H. akashiwo. Consequently, allelopathy between $S$. costatum and $H$. akashiwo may be one of the key factors that promotes monospecific bloom formation and allows both species to form alternate red tide blooms in the same ecosystem.

\section{CONCLUSIONS}

Our results from laboratory experiments that used axenic strains of Skeletonema costatum and Heterosigma akashiwo indicated that the growth of either species could be suppressed by the other, depending on cell densities. Thus, allelopathic interaction between $S$. costatum and $H$. akashiwo may play a key role in growth dynamics of red tide blooms through inhibitory effects. Furthermore, simulation using a mathematical model indicated a stable equilibrium point at which $S$. costatum and $H$. akashiwo could 
coexist. To our knowledge, there are no previous studies demonstrating that $S$. costatum suppresses the growth of a flagellate species in bi-algal culture by allelopathy. Physical, chemical, and biological factors are all involved in phytoplankton succession and interactions between $S$. costatum and $H$. akashiwo in the field. Hence, it is necessary to purify and identify allelopathic substances that affect the growth of both species, and to verify the role of allelopathy in natural phytoplankton populations.

Acknowledgements. We thank Dr. S. Toda for technical support with the growth simulation.

\section{LITERATURE CITED}

Cembella AD (2003) Chemical ecology of eukaryotic microalgae in marine ecosystems. Phycologia 42:420-447

Chen LCM, Edelstein T, Mclachlan J (1969) Bonnemaisonia hamifera Hariot in nature and in culture. J Phycol 5:211-220

Goldman JC, Dennett MR, Riley CB (1981) Test for allelopathic interactions between two marine microalgal species grown in intensive cultures. Curr Microbiol 6:275-279

Goldman JC, Riley CB, Dennett MR (1982) The effect of pH in intensive microalgal cultures. II. Species competition. J Exp Mar Biol Ecol 57:15-24

Hansen PJ (2002) Effect of high pH on the growth and survival of marine phytoplankton: implications for species succession. Aquat Microb Ecol 28:279-288

Hara Y, Chihara M (1987) Morphology, ultrastructure and taxonomy of the raphidophycean alga Heterosigma akashiwo. Bot Mag Tokyo 100:151-163

Heil CA, Glibert PM, Fan C (2005) Prorocentrum minimum (Pavillard) Schiller: a review of a harmful algae bloom species of growing worldwide importance. Harmful Algae 4: $449-470$

Honjo T (1993) Overview on bloom dynamics and physiological ecology of Heterosigma akashiwo. In: Smayda TJ, Shimizu Y (eds) Toxic phytoplankton blooms in the sea. Elsevier Science, New York, p 33-41

Honjo T (1994) The biology and prediction of representative red tides associated with fish kills in Japan. Rev Fish Sci 2: $225-253$

Honjo T, Tabata K (1985) Growth dynamics of Olisthodiscus luteus in outdoor tanks with flowing coastal water and in small vessels. Limnol Oceanogr 30:653-664

Honjo T, Shimouse T, Hanaoka T (1978) A red tide occurred at the Hakozaki fishing port, Hakata Bay, in 1973. The growth process and the chlorophyll content. Bull Plankton Soc Jpn 25:7-12

Ianora A, Miralto A, Poulet SA, Carotenuto Y and 8 others (2004) Aldehyde suppression of copepod recruitment in blooms of a ubiquitous planktonic diatom. Nature 429: 403-407

Imai I, Ishida Y, Sakaguchi K, Hata Y (1995) Algicidal marine bacteria isolated from northern Hiroshima Bay, Japan. Fish Sci 61:628-636

Iwasa Y (1998) Suri-seibutsugaku nyuumon, 2nd edn. Kyoritsu Syuppan, Tokyo, p 352

Kondo K, Seike YS, Date Y (1990) Red tides in the brackish Lake Nakanoumi. III. The stimulative effects of organic substances in the interstitial water of bottom sediments and in the excreta from Skeletonema costatum on the growth of Prorocentrum minimum. Bull Plankton Soc Jpn 37:35-47

Legrand C, Rengefors K, Fistarol GO, Granéli E (2003) Allelopathy in phytoplankton: biochemical, ecological and evolutionary aspects. Phycologia 42:406-419

Lundholm N, Hansen PJ, Kotaki Y (2005) Lack of allelopathic effects of the domoic acid-producing marine diatom Pseudo-nitzschia multiseries. Mar Ecol Prog Ser 288: 21-33

Marquardt DW (1963) An algorithm for least-squares estimation of nonlinear inequalities. SIAM J Appl Math 11:431-441

Michael W (2003) Evolution of secondary metabolites from an ecological and molecular phylogenetic perspective. Phytochemistry 64:3-19

Molisch H (1937) Der Einfluss einer Pflanze auf die andere: Allelopathie. G. Fisher Verlag, Jena

Nagasaki K, Ando M, Itakura S, Imai I, Ishida Y (1994a) Viruslike particles in Heterosigma akashiwo (Raphidophyceae): a possible red tide disintegration mechanism. Mar Biol 119:307-312

Nagasaki K, Ando M, Itakura S, Imai I, Ishida Y (1994b) Viral mortality in the final stage of Heterosigma akashiwo (Raphidophyceae) red tide. J Plankton Res 16:1595-1599

Nagasoe S, Toda S, Shimasaki Y, Oshima Y, Uchida T, Honjo $\mathrm{T}$ (2006) Growth inhibition of Gyrodinium instriatum (Dinophyceae) by Skeletonema costatum (Bacillariophyceae). Afr J Mar Sci 28:325-329

Pohnert G (2005) Diatom/copepod interactions in plankton: the indirect chemical defense of unicellular algae. Chem Biochem 6:946-959

Porter KG, Feig YS (1980) The use of DAPI for identifying and counting aquatic microflora. Limnol Oceanogr 25:943-948

Pratt DM (1966) Competition between Skeletonema costatum and Olisthodiscus luteus in Narragansett Bay and in culture. Limnol Oceanogr 11:447-455

Rice EL (1974) Allelopathy. Academic Press, New York

Rice EL (1984) Allelopathy, 2nd edn. Academic Press, New York

Schmidt LE, Hansen PJ (2001) Allelopathy in the prymnesiophyte Chrysochromulina polylepis: effect of cell concentration, growth phase and $\mathrm{pH}$. Mar Ecol Prog Ser 216: $67-81$

Smayda TJ (1998) Ecophysiology and bloom dynamics of Heterosigma akashiwo (Raphidophyceae). In: Anderson DM, Cembella AD, Hallegraeff GM (eds) Physiological ecology of harmful algal blooms. NATO ASI Ser G 41:113-131

Tarutani K, Nagasaki K, Yamaguchi M (2000) Viral impacts on total abundance and clonal composition of the harmful bloom-forming phytoplankton Heterosigma akashiwo. Appl Environ Microbiol 66:4916-4920

Uchida T, Yamaguchi M, Matsuyama Y, Honjo T (1995) The red-tide dinoflagellate Heterocapsa sp. kills Gyrodinium instriatum by cell contact. Mar Ecol Prog Ser 118:301-303

Uchida T, Toda S, Matsuyama M, Yamaguchi M, Kotani Y, Honjo T (1999) Interactions between the red tide dinoflagellates Heterocapsa circularisquama and Gymnodinium mikimotoi in laboratory culture. J Exp Mar Biol Ecol 241: 285-299

Wichard T, Poulet S, Pohnert G (2005) Determination and quantification of $\alpha, \beta, \gamma, \delta$-unsaturated aldehydes as pentafluorobenxyl-oxime derivates in diatom cultures and natural phytoplankton populations: application in marine field studies. J Chromatogr B 814:155-161 